\title{
Comparison of Relating to the Provision of Measles- Rubella Immunization in Primary Health Care in Padang
}

\author{
Masrizal $^{1 *}$, M. Jumadil Kurniawan ${ }^{1}$, Defriman Djafri ${ }^{1}$, Imraatul Hasni ${ }^{1}$ \\ \{Masrizal_khaidir@yahoo.com\}
}

Department of Epidemiology, Andalas University, Padang, West Sumatera, Indonesia ${ }^{1}$

\begin{abstract}
The study aims to understand the factor related to measles-rubella immunization in Seberang Padang health center and Air Tawar health center. This study is a comparative crossectional study, samples of 96 mothers with a proportional sampling method. Data collection is done with the questionnaire. The univariate analysis result shows $30,6 \%$ are not immunized against rubella measles in the Seberang Padang health center, $45 \%$ are not immunized at Air Tawar health center. Bivariate analysis result at Seberang Padang health center shows a p-value of knowledge. Based on the bivariate analysis, factors related to measles-rubella immunization at Seberang Padang health center are education p-value $(0,002)$, maternal attitude $(0,005)$, family support $(0,002)$, immunization information $(0,022)$. While in Air tawar health center, the related factors with measles-rubella immunization are education p-value $(0,047)$, maternal attitudes $(0,003)$, religious issues $(0,025)$, and immunization information $(0,028)$. The multivariate analysis shows that the related factors with a p-value of less than 0,05 are knowledge, maternal attitudes, religious issues, family support, and immunization information. Knowledge, maternal attitudes, religious issues, family support, and immunization information are the most influential factors with measles-rubella immunization.
\end{abstract}

Keywords: Family support, immunization information, knowledge, maternal attitude, religious issues

\section{Introduction}

Rubella, or better known as German measles, is a disease caused by the Rubella virus. Rubella is a mild disease and can be cured by itself, but the disease cause big problems if infected pregnant women. This disease can cause problems for the fetus, such as fetal growth retardation, congenital defects to abortion, which may lead to defects of the brain, heart, eyes, and ears. The rubella vaccine was introduced in 2017 to 162 countries, with global coverage reaching 52\%.[1]

Ministry of Health explained that the treatment given to patients with the disease Rubella is merely supportive because Rubella can not be treated. But Rubella can only be prevented by Immunization. So far, Indonesia provide measles immunization as one of the national immunization program. Given the magnitude estimates of the burden of disease and the 
availability of the combination vaccine Rubella Measles-Rubella (MR), it was decided to replace the Measles vaccine with measles-rubella combination vaccine, which began with mass immunization activities MR.[2]

Immunization MR (Measles Rubella) is an attempt to break the chain of transmission of measles and rubella virus are given to children aged 9 months - 15 years in order to reduce transmission of the virus to a more mature age and protect the age when entering the reproductive age. Based on the Ministry of Health (2018), the target of Indonesia by the province in 2017 in Immunization against measles / MR is equal to $89.8 \%$ for the basic Immunization for infants, whereas for continued Immunization in Baduta amounted to $62.2 \%$.[3]

According to WHO report in 2018, from 2015 - until August 2018 recorded that rubella cases decreased to 7.760 cases.[4] According to the report surveillance data last five years $70 \%$ of rubella cases occur in children aged $<15$ years. CBMS reports (Base Measles Cases Surveillance) 2017 West Sumatra Provincial Health Office, the Rubella incidence highest case rate per Regency / City of West Sumatra province in 2017 occurred in the city of Padang 54 cases. Cases of Rubella and immunization Achievement Data MR per 10 November 2018 in Padang where health centers have the achievements of Immunization Seberang Padang 71.8\% with no case and PHC freshwater own achievements MR immunization by $47 \%$ with cases.[6]

Based on the description above, researchers interested in conducting research on how the determinants associated with immunization MR in Padang by comparing two Puskesmas in Padang based health center with high cases the achievements of Immunization is low (PHC Freshwater) with Puskesmas achievements of Immunization is high and the case a low incidence (PHC Across the field) in 2019.

\section{Method}

This study is a Cross-Sectional Comparative Study. The population is all mothers of children ages 12 months - 59 months who are in Air Tawar Primary Health Care and Seberang Padang Primary Health Care. The sampling technique is proportional to random sampling with 96 mothers. Collecting data using primary data with questionnaires. Processing data using univariate analysis, bivariate analysis using the chi-square test with $95 \%$ confidence level $(\alpha=$ 0.05 ) and multivariate analysis using logistic regression,

\section{Results}

The results of the univariate analysis showed that in Seberang Padang Primary Health Care from 36 respondents, there were as many as 25 respondents $(69.4 \%)$ who have been immunized MR. Meanwhile, the Air Tawar Primary Health Care showed that out of 60 respondents, there were a total of 33 respondents (55\%) have done MR-immunized. In Seberang Padang Primary Health Care, 10 respondents (27.8\%) had a low knowledge level, while at the Air Tawar Primary Health Care 27 respondents (45\%) had a low knowledge level.

The next variable in Seberang Padang Primary Health Care on the mother's education level variables showed that 13 respondents (36.1\%) had a low education level. Meanwhile, at the Air Tawar Primary Health Care, maternal education shows that 26 respondents (43.3\%) had a low education level. According to table 1 in Seberang Padang Primary Health Care, mother attitude indicates as many as 11 respondents (30.6\%) were negative towards MR Immunization. In Air 
Tawar Primary Health Care on attitude variable, mother showed as many as 24 respondents (40\%) had negative attitudes towards MR Immunization. On the opposite Seberang Padang Primary Health Care on religious issues variable indicates that as many as 16 respondents (44.4\%) believe toward religious issues against MR immunization, while at the Air Tawar Primary Health Care religious issues indicate that as many as 25 respondents $(41.7 \%)$ believed to relieve or religious issues against MR immunization.

At Seberang Padang Primary Health Care on variable family support showed that as many as 16 respondents $(44.4 \%$ ) did not get family support for Immunization MR, while the Air Tawar Primary Health Care on the variables of family support showed that as many as 27 respondents $(45 \%)$ do not get family support for the provision of MR immunization. At the Primary Health Care in Seberang Padang, immunization information variables indicate that 16 respondents (44.4\%) did not receive MR immunization information. In Air Tawar Primary Health Care, 19 respondents $(31.7 \%)$ did not receive MR immunization information.

Table 1. Frequency Distribution-Related Determinants MR immunization in Seberang Padang and Air Tawar Primary Health Care

\begin{tabular}{lcccc}
\hline \multicolumn{1}{c}{ Variables } & \multicolumn{2}{c}{ Seberang Padang } & \multicolumn{2}{c}{ Air Tawar } \\
\cline { 2 - 4 } & f & \% & f & \% \\
\hline MR immunization & 25 & 69.4 & 33 & 55 \\
$\quad$ Yes & 11 & 30.6 & 27 & 45 \\
$\quad$ No & & & & \\
Level of Knowledge & 10 & 27.8 & 27 & 45 \\
$\quad$ Low & 26 & 72.2 & 33 & 55 \\
$\quad$ High & & & & \\
Mother's Education Level & 13 & 36.1 & 26 & 43.3 \\
$\quad$ Low & 23 & 63.9 & 34 & 56.7 \\
$\quad$ High & 11 & 30.6 & 24 & 40 \\
Mother's attitude & 25 & 69.4 & 36 & 60 \\
$\quad$ Negative & & & & \\
$\quad$ Positive & 16 & 44.4 & 25 & 41.7 \\
Religious issues & 20 & 55.6 & 35 & 58.3 \\
$\quad$ Believe & & & & \\
$\quad$ Do not believe & 16 & 44.4 & 27 & 45 \\
Family support & 20 & 55.6 & 33 & 55 \\
$\quad$ No & & & & \\
$\quad$ Yes & 16 & 44.4 & 19 & 31.7 \\
Immunization information & 20 & 55.6 & 41 & 68.3 \\
$\quad$ No & & & & \\
$\quad$ Yes & & & & \\
\hline & & & & \\
\hline
\end{tabular}

Table 2. Relationship Dependent Variables with an independent variable in Seberang Padang Primary Health Care

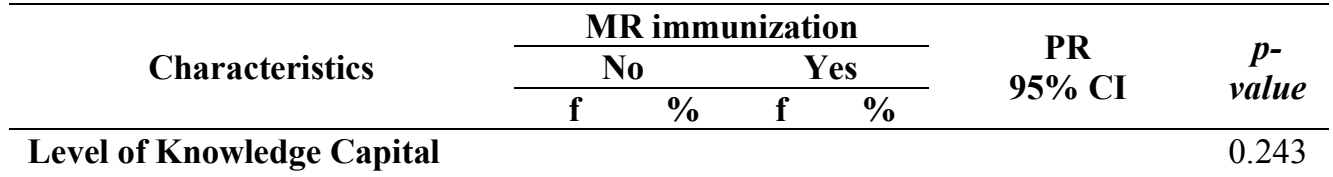




\begin{tabular}{|c|c|c|c|c|c|c|}
\hline Low & 5 & 50 & 5 & 50 & 2,167 & \\
\hline High & 6 & 23.1 & 20 & 76.9 & $(0.850-5.526)$ & \\
\hline \multicolumn{7}{|c|}{ Education level of mother } \\
\hline Low & 8 & 61.5 & 5 & 38.5 & 4.718 & \multirow[t]{2}{*}{0.002} \\
\hline High & 3 & 13 & 20 & 87 & $(1.510-14.743)$ & \\
\hline \multicolumn{7}{|l|}{ attitude Mother } \\
\hline Negative & 7 & 63.6 & 4 & 36.4 & 3,977 & \multirow{2}{*}{0.005} \\
\hline Positive & 4 & 16 & 21 & 84 & $(1.459-10.845)$ & \\
\hline \multicolumn{7}{|l|}{ Religious issues } \\
\hline Believe & 6 & 37.5 & 10 & 62.5 & 1,500 & \multirow[t]{2}{*}{0.659} \\
\hline Do not believe & 5 & 25 & 15 & 75 & $(0.558-4.029)$ & \\
\hline \multicolumn{7}{|l|}{ Family support } \\
\hline No & 16 & 59.3 & 11 & 40.7 & 5.625 & \multirow[t]{2}{*}{0.002} \\
\hline Yes & 2 & 10 & 18 & 90 & $(1.410-22.448)$ & \\
\hline \multicolumn{7}{|c|}{ Immunization information } \\
\hline No & 8 & 50 & 8 & 50 & 3,333 & \multirow{2}{*}{0.022} \\
\hline Yes & 3 & 15 & 17 & 85 & $(1.053-10.555)$ & \\
\hline
\end{tabular}

Based on table 2 indicate that the results of the bivariate analysis on Seberang Padang Primary Health Care, there is no relationship between the level of mother's knowledge ( $p=$ $0,243)$ and religious issues $(p=0.659)$ with $M R$ immunization. There is a significant relationship between the level of mother's education $(p=0.002)$, mother's attitude $(p=0.005)$, family support $(p=0.002)$ and immunization information $(p=0.022)$ with MR immunization.

Based on Table 3 shows that in Air Tawar Primary Health Care, there is no relationship between the level of knowledge of mothers $(p=0.081)$ and family support $(p=0.081)$ with immunization MR. There is a significant relationship between the level of education of mothers $(p=0.047)$, the attitude of mothers $(p=0.003)$, religious issues $(p=0.025)$, and immunization information $(\mathrm{p}=0.028)$ with immunization MR.

Table 3. Relationship Dependent Variables with an independent variable in Air Tawar Primary Health Care

\begin{tabular}{|c|c|c|c|c|c|c|}
\hline \multirow{3}{*}{ Characteristics } & \multicolumn{4}{|c|}{ MR immunization } & \multirow{3}{*}{$\begin{array}{c}\text { PR } \\
95 \% \mathrm{CI}\end{array}$} & \multirow{3}{*}{ p-value } \\
\hline & \multicolumn{2}{|c|}{ No } & \multicolumn{2}{|c|}{ Yes } & & \\
\hline & f & $\%$ & f & $\%$ & & \\
\hline \multicolumn{7}{|l|}{ Level of Knowledge } \\
\hline Low & 16 & 59.3 & 11 & 40.7 & 1.778 & \multirow[t]{2}{*}{0081} \\
\hline High & 11 & 33.3 & 22 & 66.7 & (1.000 to 3.159$)$ & \\
\hline \multicolumn{6}{|l|}{ Education level of mother } & \multirow{3}{*}{0047} \\
\hline Low & 16 & 61.5 & 10 & 38.5 & 1,902 & \\
\hline High & 11 & 32.4 & 23 & 67.6 & (1.072 to 3.347$)$ & \\
\hline \multicolumn{7}{|l|}{ Attitude Mother } \\
\hline Negative & 17 & 70.8 & 7 & 29.2 & 2,550 & \multirow[t]{2}{*}{0003} \\
\hline Positive & 10 & 27.8 & 26 & 72.2 & (1.419 to 4.582$)$ & \\
\hline \multicolumn{6}{|l|}{ Religious issues } & \multirow{2}{*}{0025} \\
\hline Believe & 16 & 64 & 9 & 36 & 2,036 & \\
\hline
\end{tabular}




\begin{tabular}{lcccccc}
$\begin{array}{l}\text { Do not believe } \\
\text { Family support }\end{array}$ & 11 & 31.4 & 24 & 68.6 & $(1.151$ to 3.604$)$ & \\
$\quad$ No & 16 & 59.3 & 11 & 40.7 & 1.778 & 0081 \\
$\quad \begin{array}{l}\text { Yes } \\
\text { Immunization information }\end{array}$ & 11 & 33.3 & 12 & 66.7 & $(1.000$ to 3.159$)$ & \\
$\quad$ No & 13 & 68.4 & 6 & 31.6 & 2,004 & 0028 \\
$\quad$ Yes & 14 & 34.1 & 27 & 65.9 & $(1.187$ to 3.382$)$ & \\
\hline \multicolumn{1}{r}{ Total } & $\mathbf{2 7}$ & $\mathbf{4 5}$ & $\mathbf{3 3}$ & $\mathbf{5 5}$ & & \\
\hline
\end{tabular}

Table 4. Results of Logistic Regression Analysis and Full Model First Stage Final

\begin{tabular}{|c|c|c|c|c|c|}
\hline \multirow{2}{*}{ variables } & \multirow{2}{*}{$\begin{array}{c}\text { value } \\
\text { SE }\end{array}$} & \multirow{2}{*}{ p-value } & \multirow{2}{*}{ PR } & \multicolumn{2}{|c|}{$95 \%$ CI } \\
\hline & & & & Lower & Upper \\
\hline Level of Knowledge Capital & 0.676 & $0,028 *$ & 4.422 & 1,176 & 16.623 \\
\hline Education level of mother & 0644 & 0.092 & 2,962 & .838 & 10.473 \\
\hline attitude Mother & 0.615 & $0,004 *$ & 5.987 & 1.794 & 19.978 \\
\hline Religious issues & .631 & $0,012 *$ & 4.908 & 1,426 & 16.890 \\
\hline Family support & 0.606 & $0,004 *$ & 5.812 & 1,772 & 19.058 \\
\hline Immunization information & .607 & $0,027 *$ & 3.832 & 1,167 & 12.584 \\
\hline
\end{tabular}

"A significant variable (p-value $<\mathbf{0 . 0 5})$

Based on Table 4 shows that the level of knowledge of the mother, maternal attitudes, religious issues, family support immunization information is the most dominant variable effect on MR Immunization on the second Puskesmas with values $(\mathrm{p}<0.05)$.

\section{Discussion}

Based on the research that has been done is obtained at the Seberang Padang Primary Health Care, $69.4 \%$ of respondents have done MR immunization, 30.6\% have not done MR immunization. Meanwhile, in Air Tawar Primary Health Care, 55\% of respondents have done MR Immunization, and 45\% of respondents have not done MR immunization for their children. The results are consistent with research conducted Prabandari (2018) that the number of mothers who had done MR Immunization more than mothers who had not done the MR immunizations [7].

Frequency distribution of research results on the mother's level of knowledge Seberang Padang Primary Health Care showed that mothers who have a high level of knowledge as much as $72.2 \%$, while the level of knowledge of mothers was lower by $27.8 \%$. And also on Air Tawar Primary Health Care showed that $55 \%$ of mothers had a high knowledge level, and $45 \%$ of mothers had a low knowledge level. The results are consistent with research Pramitasari (2018) states that knowledge is the result of human sensory or know the results obtained from the person to the object through the senses, so that if the knowledge is the better, the higher is expected to influence the person's behavior.[8]

The results of the study the frequency distribution of mother's education level on Seberang Padang Primary Health Care showed that mothers who have higher education levels as much as $63.9 \%$ while those with a low education level of only $36.1 \%$. And at Air Tawar Primary Health Care mothers who have higher education levels as much as $56.7 \%$ while those with a low 
education level of $43.3 \%$. The results are consistent with research conducted by Triana (2016), highly educated mothers more than low educated mothers.[9]

Results of research on the frequency distribution of maternal attitude Seberang Padang Primary Health Care showed that $69.4 \%$ of respondents have a positive attitude while $30.6 \%$ have a negative attitude. Air Tawar Primary Health Care by $60 \%$ of respondents have a positive attitude, and $40 \%$ of respondents have a negative attitude. The results are consistent with research conducted by Pramitasari (2018) that mothers who have a positive attitude more than in women who had a negative attitude. [8]

The results of the study the frequency distribution of religious issues in Seberang Padang Primary Health Care show $55.6 \%$ do not believe in religious issues against MR immunization, and $44.4 \%$ believe in religious issues. Similarly, Air Tawar Primary Health Care that more respondents who do not believe in religious issues concerning MR immunization is equal to $58.3 \%$ compared with $41.7 \%$ who believe.

The results of the study the frequency distribution of family support to Seberang Padang Primary Health Care indicates that more respondents support from families with a percentage figure that is $55.6 \%$ compared to no family support with a percentage of $44.4 \%$. In Air Tawar Primary Health Care that respondents get family support by $55 \%$, while that did not get the support of $45 \%$. The results are consistent with research Arista (2016) that mothers get the support of family more than in women who do not get family support.[10]

Frequency distribution of research findings on the health center immunization information Seberang Padang Primary Health Care indicate that as many as $55.6 \%$ of mothers receive immunization information, while $44.4 \%$ of mothers did not receive immunization information. Air Tawar Primary Health Care for $68.3 \%$ of mothers receive immunization information, and $31.7 \%$ did not receive immunization information. The results are consistent with the research conducted by Triana (2016) that mothers get more information about Immunization than in women who did not get the information.[9]

The results showed that the relationship between the level of knowledge of mothers with Immunization at Seberang Padang Primary Health Care is p-value equal to 0243. The p-value at the Air Tawar Primary Health Care obtained 0081, which means the two Primary Health Care is no significant relationship between the level of knowledge of mothers with MR immunization.

The level of knowledge of the mother is in line with research conducted Destiyanta argues that there is no relation between knowledge and the accuracy of the schedule following the measles immunization with a p-value of 0.122 (p> 0.05) [11]. It is also in line with Makamban's research in Makassar that there is no relationship between the level of knowledge of the mother with the provision of fully immunized children under five with p-value $0,087.12$ [12]. However, the current finding is not in line with Yuda's research, which indicated that the better knowledge of the mother, the greater the chances of the mother have Immunization.[13]

The results showed that the relationship between education level of mothers with Immunization at Seberang Padang Primary Health Care was obtained p-value $0.002(p<0.05)$, and the value of $\mathrm{PR}=4.1(95 \% \mathrm{CI})$, and the Air Tawar Primary Health Care was obtained $\mathrm{p}$ value $0.047(p<0.05)$, and the value of $P R=1.9(95 \% \mathrm{CI})$, indicating that there is a significant relationship between the level of education of mothers with immunization MR on both the health center.

The results of the study variables maternal education level is in line with research Arista which indicated the relationship between the level of education with a history of giving basic Immunization in infants in Paal V Primary Health Care Jambi, with OR (odds ratio) showed $56,250.10$. However, the result of the current study was not in line with research Candrasari which suggests that the results of statistical tests using Fisher's exact test p-value of 0.262 (p> 
0.05). It indicated there is no significant relationship between mother's education with the participation interest MR vaccination.

The results showed that the relationship between the attitude of mothers with Immunization at Seberang Padang Primary Health Care was obtained p-value of $0.005(\mathrm{P}<0.05)$ with the value of $\mathrm{PR}=3.9(95 \% \mathrm{CI})$. In the Air Tawar Primary Health Care was obtained p-value $=0003$ with a value of $\mathrm{PR}=2.5(95 \% \mathrm{CI})$, which means that there is a significant correlation between maternal attitudes to Immunization MR in both regions.

Results of the study variables mother's attitude are in line with research Pramitasari (2018), which suggests that there is a relationship with the attitude of immunization compliance in following the measles-rubella (MR) with $\rho$-value of $0.027<0,05.8$ This may imply that there is a significant relationship between attitude with obedience. And also on research Yuda (2018) Statistical analysis showed that there is a significant association between maternal attitudes about immunization compliance [13]

The research shows that the relationship between religion and immunization issues in Seberang Padang Primary Health Care MR was obtained p-value 0.659 ( $p>0.05$ ). It indicates that there is no significant relationship between religious issues with MR immunization in Seberang Padang Primary Health Care. But in Air Tawar Primary Health Care was obtained pvalue of $0.025(\mathrm{p}<0.05)$, with the value of $\mathrm{PR}=2(95 \% \mathrm{CI})$, which means there is a significant relationship between religious issue with MR immunization in Air Tawar Primary Health Care.

As we know, many negative issues circulating in the community about MR immunization makes people afraid and hesitant in giving their children MR-immunized because some believe that MR Immunization unlawful / prohibited. However, MUI (Indonesian Ulema Council) has issued a fatwa on Immunization permissible (permissible) as a form of efforts to achieve immunity (immunity) and prevent the occurrence of a specific disease, but at present, about the religious issues, MR immunization is still pros and cons in the community. Where the results of statistical tests based on Seberang Padang Primary Health Care, there was no correlation with MR immunization, while the Air Tawar Primary Health Care correlation with MR immunization.

The results showed that the relationship between family support immunization in Seberang Padang Primary Health Care was obtained p-value $=0.002(\mathrm{p}<0.05)$, with the value of $\mathrm{PR}=$ $5.6(95 \% \mathrm{CI})$. It means there is a significant relationship between family support provision MR immunization in Seberang Padang Primary Health Care. The result is in line with research Utami (2014), who argued that the statistical test result obtained by the P-value of $0.000(\mathrm{P}<0.05)$ and $95 \%$ confidence level. It can be concluded that there is a significant relationship between family support maternal motivation in getting basic Immunization Detailed in the village of West Nyabakan.

While at the Air Tawar Primary Health Care was obtained p-value of 0081, which means that there is a significant relationship between family support MR immunization. The results are consistent with research Hermayanti (2016) that of the p-value Statistical test results obtained in Ho acceptable decision ( $p>0.05$ ), which means there is no significant relationship between family support with the completeness of basic Immunization.

The results showed that the relationship immunization with immunization information on Seberang Padang Primary Health Care $\mathrm{p}$-value $=0.022(\mathrm{P}<0.05)$ with the value of $\mathrm{PR}=3.3$ $(95 \%$ CI $)$. Meanwhile, in Air Tawar health center, $p$-value $=0.028(\mathrm{p}<0.05)$ with the value of $\mathrm{PR}=2(95 \% \mathrm{CI})$. It means that there is a significant association between Immunization with immunization information MR on both the health center.

The results of the study variables immunization information in line with research conducted by Triana (2016) that the statistical analysis on the variable immunization information obtained 
p-value of 0.04 (p-value $<0.05$ ), means the significant correlation between information about Immunization with complete basic Immunization in infants in the district of Padang Kuranji 2015 with a value of $\mathrm{PR}=1.92(95 \% \mathrm{CI}: 1,122,64)$. It indicates that parents get a little information neighbor immunization 1.92 times greater risk of not giving immunizations a complete base to the baby from the mother to get enough information about information.[9] Multivariate analysis showed that the level of knowledge of the mother, maternal attitudes, religious issues, family support, and information about Immunization is the most dominant variable affecting MR immunization on both Primary Health Care.

\section{Conclusion}

The number of mothers who have given MR immunizations to their children is greater than those who did not provide MR immunizations to the two Primary Health Care. And in the bivariate analysis, there is a significant relationship between the level of maternal education, maternal attitudes, family support, immunization information, and the provision of MR immunization at the Seberang Padang Primary Health Care. And there is a significant relationship between the level of maternal education Air Tawar Primary Health Care.

It is expected that health workers will continue to maintain and improve health services, provide health promotion regarding MR immunization to the community. The cadres have to be more active in inviting the public to come to posyandu to get more information about Immunization so that mothers become aware and not easily believe in issues. The negative issues that prevent the mother from giving MR immunization to her child, so that this can influence the attitude of the mother in giving MR immunization.

\section{Suggestion}

Expected to health workers to maintain and improve health services, provide health promotion regarding immunization $\mathrm{MR}$ to the community, as well as more active cadre invites the public to come to Posyandu to get more information about Immunization, so that the mother came to know and do not easily believe to relieve or negative issues that inhibit the Immunization MR mother to her child, so as to influence the attitudes of mothers in Immunization MR.

\section{References}

[1] Jannah AudWS. Knowing and Understanding the Dangers of TORCH (Toxoplasma, Rubella, CMV, and Herpes Simplex II) For Pregnant Women and Fetuses in Their Womb. Yogyakarta: Katahati Publisher; 2015.

[2] Directorate General of P2P. Technical Guidelines for Measles Rubella (MR) Immunization Campaign. Jakarta: Ministry of Health of the Republic of Indonesia; 2017.

[3] Ministry of Health. Indonesia Health Profile Data and Information 20172018. 
[4] WHO. Global Measles and Rubella Update October 20182018 [cited 2018].

[5] Provincial Health Office of West Sumatra. CBMS (Cases Base Measles Surveillance) Results 2017 May 2018. Padang: West Sumatra Provincial Health Office; 2018.

[6] Padang City Health Service. Measles Rubella (MR) Immunization Pocket Book. Padang: Padang City Health Office; 2018.

[7] Prabandari GM, Syamsulhuda B, Kusumawati A. Several Factors Related to the Acceptance of Mothers Against the Immunization of Measles Rubella in Elementary Children in Gumpang Village, Kartasura District, Sukoharjo. District Public Health Journal (e-Journal). 2018; 6 (4): 573-81.

[8] Pramitasari DA, Princess IRP. The Relationship between Mother's Knowledge and Attitudes With Compliance in Following Mass Measles-Rubella (MR) Immunization in Posyandu The working area of Nganglik II Health Center, Sleman Regency, Yogyakarta. The shine of light d-iii world of nursing. 2017; 2 (2)

[9] Triana V. Factors Related to Provision of Complete Basic Immunization in Infants in 2015. Journal of Andalas Community Health. 2016; 10 (2): 123-35.

[10] Arista D, Hozana H. Relationship between Education Level, Family Support and the Role of Health Workers with a History of Basic Immunization in Infants in the Work Area of Paal V Health Center in Jambi City 2016. Scientia Journal. 201

[11] Destiyanta AP. The Relationship between the Level of Education, Employment, and Mother's Knowledge with Accurate Schedule to Follow Measles Immunization in the Work Area of Weru Sukoharjo Health Center (Doctoral dissertation, Muhammadiyah University, Surakarta).

[12] Makamban Y, Salmah U. Factors related to coverage of complete basic Immunization in infants in the work area of the Puskesmas Antara Makassar City. 2014.

[13] Yuda AD, Nurmala I. The Relationship of Characteristics, Knowledge, Attitudes, and Mother's Action on Immunization Compliance. Periodical Journal of Epidemiology. 2018 Aug 30; 6 (1) 86-94 